\title{
Independent high voltage DC source development for renewable-grid integration interface
}

\author{
Omar Abu Hassan', Shamsul Aizam Zulkifli², Mohd Shamian Zainal ${ }^{3}$, Ahmad Alabqari Ma' Radzi ${ }^{4}$, \\ Muhammad Shukri Ahmad ${ }^{5}$, Tengku Nadzlin Tengku Ibrahim ${ }^{6}$ \\ ${ }^{1,3}$ Faculty of Engineering Technology, Universiti Tun Hussein Onn Malaysia, Hub Pendidikan Tinggi Pagoh, Malaysia \\ ${ }^{2}$ Faculty of Electrical and Electronic Engineering, Universiti Tun Hussein Onn Malaysia, Malaysia \\ ${ }^{4,5,6}$ Centre for Diploma Studies, Universiti Tun Hussein Onn Malaysia, Hub Pendidikan Tinggi Pagoh, Malaysia
}

\begin{abstract}
Article Info
Article history:

Received Aug 27, 2019

Revised Oct 8, 2019

Accepted Dec 7, 2019

Keywords:

DC link sources

Dual H-bridges

HF Transformer

Magnetic material losses

Renewable energy

ABSTRACT

Recent advancement in renewable-grid integration research, due to the concern on the environmental impact, leads to extensive study in isolated power converter as their interface. As part of isolation capability in power converter interface, extensive study of magnetic component has been carried out, especially on the design, construction and optimisation to achieve optimal operation. One of the main issue in verifying the analytical power loss model is to have independent HVDC link power source for an experimental validation work. This paper focus on the design and construction of DC link source, to be use in the experimental rig setup. Several DC link source option has been evaluated, and TDK-lambda PF500360 A power supply was selected due to the availability and excellent energy efficiency offered, at better price. External circuit is designed and implemented to achieve desired voltage and current supply characteristic. At the end, the voltage and current of the DC link supply for Dual H-bridges is obtained and shown promising result for experimental rig measurement and data collection work.
\end{abstract}

This is an open access article under the CC BY-SA license.

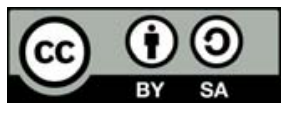

\section{Corresponding Author:}

Omar Abu Hassan,

Departement of Electrical Engineering Technology, Faculty of Engineering Technology,

Universiti Tun Hussein Onn Malaysia,

Hab Pendidikan Tinggi Pagoh, 84600 Muar, Johor, Malaysia

Email: omarh@uthm.edu.my

\section{INTRODUCTION}

Renewable energy and grid integration require several power converter, with or without bidirectional functionality, as an interface between renewable generation, energy storage and grid system [1-6]. One of the main area of interest in renewable-grid integration is the construction and optimisation of magnetic component for power converter [7,8] which contribute to size and efficiency issue of the system [9-13]. Evaluation and analytical validation work for magnetic component [14-20] study (high frequency transformer) require dual H-bridge DC/DC converter system [21-25].

Therefore, the development of independent HV DC-link source has to be implement and construct, in order to provide the high voltage direct current (DC) to the DC-link side of the dual H-bridge DC/DC converter system as shown in Figure 1. Several choices of after market DC source supply can be used, ranging from variable dc output power supply that is ready to be use, to a fixed dc output voltage power supply which require construction of external circuit in order to operate. In this paper, power supply module, PF500A-360 are selected due to the module availability, inexpensive and within desired specification [26].

Journal homepage: http:// ijpeds.iaescore.com 


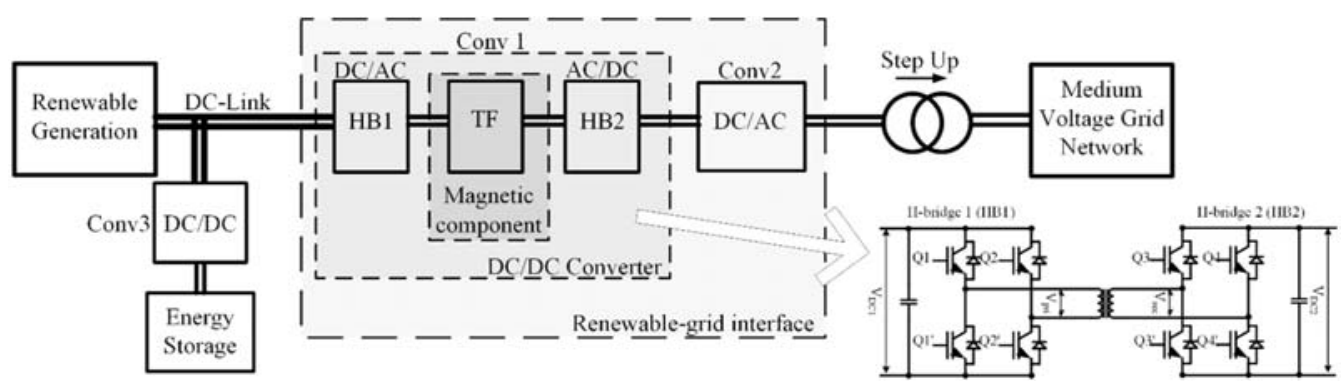

Figure. 1. Renewable system-grid integration interface using power converter

This power module offer easy solution to connect to the H-bridge converter system that has $360 \mathrm{Vdc}$ input from AC mains with wide range of inputs, achieved a power factor of 0.95 and able to offer the maximum 750 watt output power at high line inputs, which is capable enough to supply to the H-bridge converter system as on Figure 2.

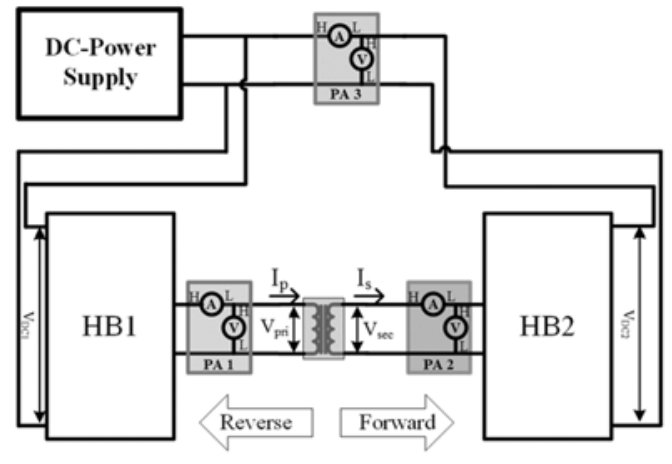

Figure. 2. Intended area of DC source supply that used to provide power for Dual H-bridges power circulation

Other features of this power supply module is thermal protection, inrush limiting circuit, overvoltage protection, maximum of $94 \%$ efficiency full load $250 \mathrm{Vac}$ supply, as well as complied with EN60950 standard [27]. This project focusing on the construction of High Voltage DC-link power source based on selected module, to facilitate experimental setup mentioned in Figure 2. Next section discussed more detail on the parameters and circuit for this work.

\section{EXTERNAL CIRCUIT CONSTRUCTION}

For the power supply module to work properly and safely, external circuit and circuit LED indicator have to be build.

\subsection{External circuit parameter}

This section is the description and the calculation of each external parts of the power supply (shown on Table 1. On the input supply side, three external components have to be added, which is $10 \mathrm{~A}$ fuse (F1), noise filter, and also input capacitor $\left(C_{l}\right)$ with recommended value of $1 \mathrm{uF} 250 \mathrm{Vac}$. The function of this $C_{l}$ is to provide high frequency noise filter and also reduce unwanted oscillation by placing it closely to the terminal.

Meanwhile, on the output side, capacitor $C_{2}$, capacitor $C_{3}$, capacitor $C_{4}$ and DC fuse F2 value is suggested by power module manufacturer and obtained from application notes [26]. The function of capacitor $C_{2}$ and $C_{3}$ is used to snub the spike noise from boost inverter and capacitor $C_{4}$ is to reduce the common mode circulating current. 
Table 1. External circuit parameter

\begin{tabular}{|c|c|c|c|}
\hline \multicolumn{4}{|c|}{ External component } \\
\hline \multicolumn{2}{|c|}{ Input Side } & \multicolumn{2}{|c|}{ Output Side } \\
\hline Item & Value & Item & Value \\
\hline Fuse, F1 & $10 \mathrm{~A}$ & Fuse, F2 & $3 \mathrm{~A} 500 \mathrm{Vdc}$ \\
\hline $\mathrm{C} 1$ & $1 \mathrm{uF}, 250 \mathrm{~V}$ & $\mathrm{C} 2$ & $0.94 \mathrm{uF} 630 \mathrm{~V}$ \\
\hline & & $\mathrm{C} 3$ & $0.47 \mathrm{uF} 630 \mathrm{~V}$ \\
\hline & & $\mathrm{C} 4$ & $3300 \mathrm{pF} 400 \mathrm{~V}$ \\
\hline
\end{tabular}

\subsection{Inrush limiting current and output capacitor}

During the DC source operation start-up, one of the main issued faced is high surge current, before its reaching steady state. The instantaneous surge current, drawn by power supply is called inrush current or turn-on current [28-30]. This current can be as high as 20 times steady state current, and can caused damaged to power supply load. Therefore, inrush limiting circuit is required, which consist of resistor that can be calculated as (1)

$$
R_{\text {inrush }}=\frac{V_{\text {in }} \times \sqrt{2}}{I_{\text {inrush }}}[\Omega]
$$

Where, Rinrush=external resistor value, $V_{\text {in }}=\mathrm{AC}$ RMS input voltage, and Iinrush=inrush current. On the other hand, output capacitor $C_{o}$ calculated as below (2) to maintain peak to peak voltage of less than $15 \mathrm{~V}$ peak to peak. External output capacitor, $C_{o}$, are required to ensure DC-link voltage is constant for line and load change [26, 27, 31]. Mathematical equation to determine the capacitance needed for minimum peak to peak ripple output voltage is (2)

$$
C_{o} \geq \frac{P_{\text {out }}}{2 \pi f \times V_{p-p} \times V_{o} \times \eta}[F]
$$

Where, $C o=$ Output smoothing capacitor, $P_{\text {out }}=\mathrm{P}_{\text {in }}$ of H-bridge inverter module, $f=$ input frequency, $V_{p-p}=$ output ripple voltage, $V_{o}=$ rated output voltage of power module, and $\eta=$ efficiency of power module. Secondly, the output capacitance must also be calculated based on the required holdup time of AC/DC power supply. Formula to determine the capacitance value based on this holdup time shown (3).

$$
C_{o} \geq \frac{2 \times\left(\frac{P_{o}}{\eta}\right) \times t_{\text {holdup }}}{\left(V_{o}-\frac{V_{p-p}}{2}\right)^{2}-V_{\min ^{2}}}[F]
$$

Where, $C_{o}=$ Output smoothing capacitor, $P_{o}=P_{\text {in }}$ of H-bridge inverter, $\eta=$ efficiency of the H-bridge inverter, tholdup=holdup time for $\mathrm{AC} / \mathrm{DC}$ power supply, $V_{o}=$ rated output voltage, $V_{p-p}=$ output ripple voltage and $V_{\min }=$ minimum input voltage of the H-bridge converter.

Figure 3 (a) shows the complete circuit diagram with the component calculated. Once the external circuit is build and connected as on Figure 3 (b), the testing is carried on to the power supply module to obtain and observe the ability of the power supply module to operate as it should.

The operation of power module have several control feature and require several steps before reaching steady state and full controlled mode. One of the feature is overvoltage protection (OVP) mode which detect increase in voltage over its limit of $390 \mathrm{~V}$. If output voltage is over $390 \mathrm{~V}$, OVP will be trigger and trip, thus, reduce the output voltage to $\sqrt{2}$ from AC RMS input voltage and output current to zero.

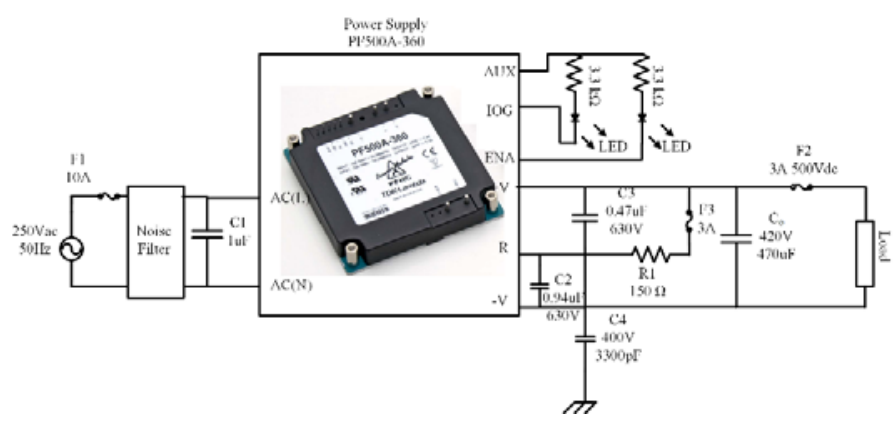

(a)

Int J Pow Elec \& Dri Syst Vol. 11, No. 1, Mar 2020 : $374-381$ 


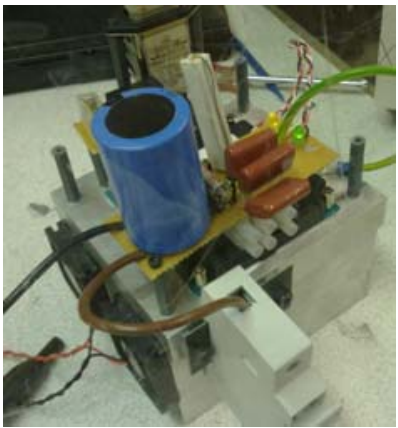

(b)

Figure 3. (a) The circuit construction of the power supply module, PF500A-360, (b) Prototype model of high voltage DC source supply

\section{TESTING EVALUATION AND RESULT}

The constructed power supply module is then applied to the AC input voltage either from auto

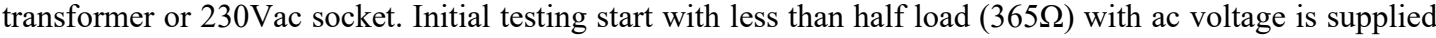
from auto transformer and the input is increase slowly to the maximum.

\subsection{Hot start at full load}

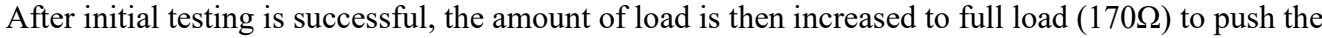
DC-link source drawing maximum current on the DC output side.

In Figure 4, the rectifier power supply achieved stability in the operation with the maximum output current of $2.1 \mathrm{~A}(358 \mathrm{~V} / 170 \Omega)$. Can be observed that this power supply module have a number of step before its entering stability and full controlled mode, power module sequence chart. It is start with the capacitor charging mode using $150 \Omega$ an inrush resistance which drawing about $2.37 \mathrm{~A}$ current.

This process takes approximately $85 \mathrm{~ms}$, and once capacitor is charged, system goes into diode rectifier mode where DC output voltage is equal AC peak input voltage. Then, this power supply will enter full controlled mode system at almost $360 \mathrm{~V}$ voltage. After achieved steady state, can be seen that the input

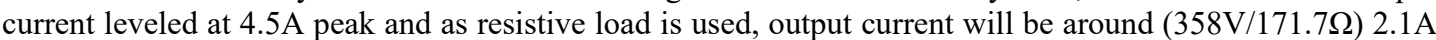
which is maximum current that the system can supply.
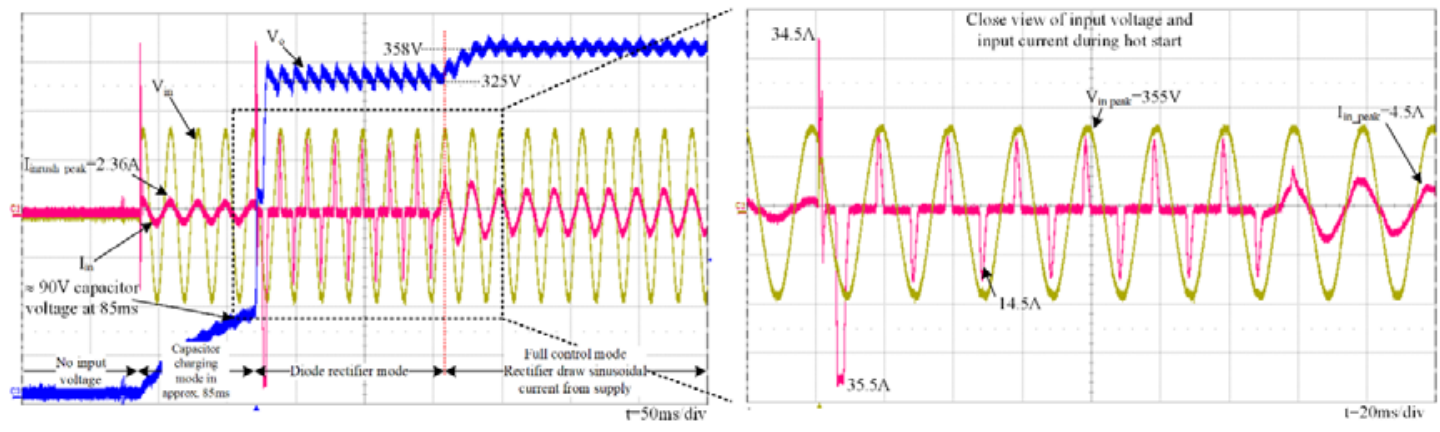

Figure 4. Input AC voltage, input current and output voltage during hot start of power supply with full load

\subsection{Hot start with no load}

Testing without the load (open circuit at the output) also shows the same steps as in the full load test and the result showed in Figure 5. However, there is no current drawing from the system once system in the full controlled mode. Meanwhile, same result appeared during the capacitor charge mode where the system used an inrush resistance as the load and drawing about 2.35A current. This step is required to make sure the safety of the capacitor, to prevent sudden voltage increased in the capacitor which will caused high current spike. 

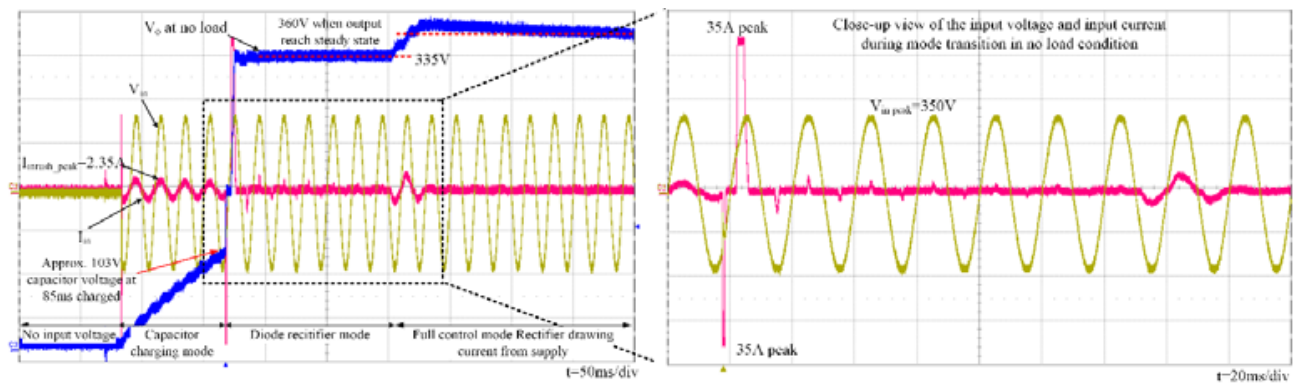

Figure 5. Input AC voltage, input current and output voltage during hot start with no load present

\subsection{Operation between full load and no load}

Power supply is also run at full voltage and testing both from no load to the full load and full load to no load and the result shown in Figure 6. It is appeared that the power supply behaving properly although there is sudden load is applied to the system. During the operation from no load to the full load, DC output voltage show some voltage dip (about 40V) and taking about 0.4 second to reach the steady state again. However, when removing the load while power supply at full supply, the system taking a longer time to stabilized again $(0.6$ second). However, both testing shows the ability of the power supply to handle the sudden changed in the load.
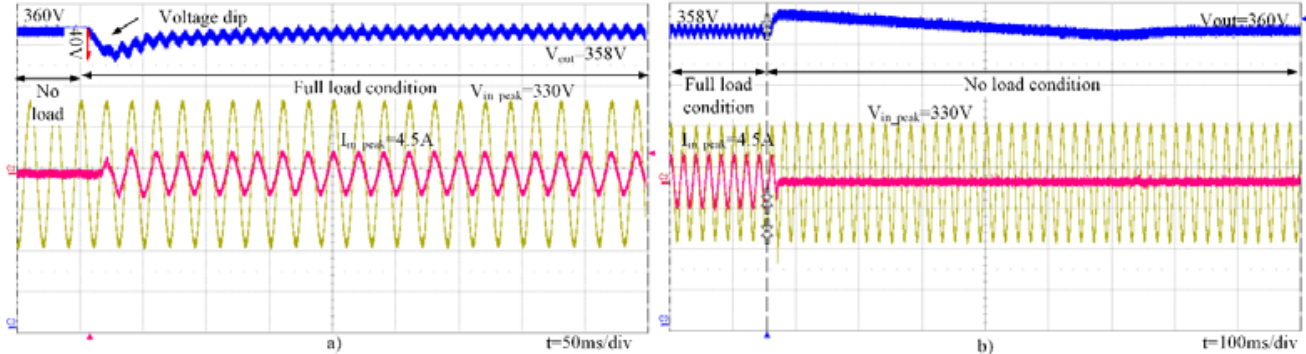

Figure 6 . The output voltage, input voltage and input current during sudden load changed at full controlled mode operation.

\subsection{Final test with main outlet supply}

Finally, startup test using the power socket outlet at both full load operation and also full load to no load operation. The result shows in Figure 7 where the same 4 steps are required before it enter full controlled mode (steady state mode).
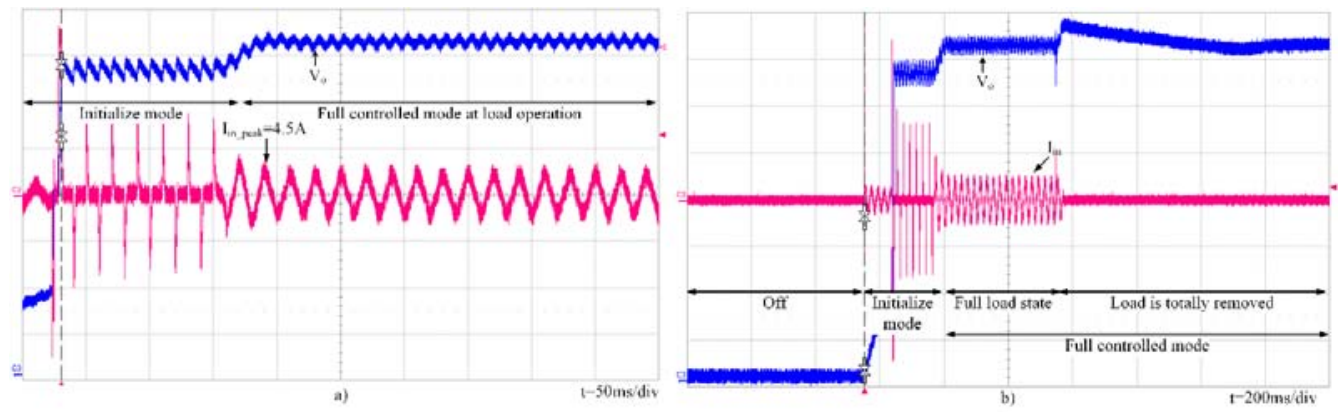

Figure 7. Output voltage and input current of power supply module using 230Vrms socket supply; a) start-up system until steady state is reached, b) start-up system then immediately remove the load.

Int J Pow Elec \& Dri Syst Vol. 11, No. 1, Mar 2020 : 374-381 


\section{CONCLUSION}

As a conclusion, this power supply is properly tested and able to provide high voltage supply the $\mathrm{H}$ Bridge system. However, there is one limitation that needs to be resolved which is high value of the capacitance in the DC-link when this power supply is connected to the H-bridge system. This problem caused the system to draw excessive amount of current and might damage the power supply. One solution is to add the small value of resistance during the startup which is parallel with the DC fuse on the output side. The resistance limit the inrush current during the startup and once the system reach stability, DC fuse can be connected using contactor or some kind of switch. However, this method needs to be properly implemented to make sure the safety of the high voltage power supply operation, used in the experimental setup. In the end, additional validation are require before power supply can be fully implemented to the experimental setup for HF transformer evaluation.

\section{ACKNOWLEDGEMENTS}

This work was done in collaboration with Power Energy Focus Group of Faculty of Engineering Technology, Advance Control Power Converter Team of Faculty of Electrical and Electronic Engineering, and Centre for Diploma Studies, Universiti Tun Hussein Onn Malaysia (UTHM). This work was financially supported by Tier-1 grant U854 UTHM and the author would like to thank to everyone involved for technical support.

\section{REFERENCES}

[1] H. Fan and H. Li, "High frequency high efficiency bidirectional DC-DC converter module design for $10 \mathrm{kVA}$ solid state transformer," Conf. Proc. - IEEE Appl. Power Electron. Conf. Expo. - APEC, pp. 210-215, 2010.

[2] S. Member and É De Technologie, "Analysis, design and control of a standalone hybrid renewable energy conversion system," pp. 1-8, 2013.

[3] M. Beykverdi, A. Jalilvand, and M. Ehsan, "Cooperative energy management of hybrid DC renewable grid using decentralized control strategies," Energies, 2016.

[4] J. M. Carrasco et al., "Power-electronic systems for the grid integration of renewable energy sources : a survey," IEEE Trans. Ind. Electron., vol. 53, no. 4, pp. 1002-1016, 2006.

[5] C. Klumpner, G. Asher, and G. Z. Chen, "Selecting the power electronic interface for a supercapattery based energy storage system," in PowerTech, 2009 IEEE Bucharest, pp. 1-7, 2009.

[6] Y. Shi, R. Li, Y. Xue, and H. Li, "High-frequency-link-based grid-tied PV system with small DC-link capacitor and low-frequency ripple-free maximum power point tracking," IEEE Trans. Power Electron., vol. 31, no. 1, pp. 328-339, 2016.

[7] A. Suresh Kumar, R. K. Pongiannan, C. Bharatiraja, A. Yusuff, and N. Yadaiah, "Non isolated coupled converter tied voltage source inverter drive," International Journal of Power Electronics and Drive System (IJPEDS), vol. 10, no. 2, 2019.

[8] Sarun Soman, Nishtha Shelly and S. K. T. Ciji Pearl Kurian, "DC transformer modelling and control of DC-DC buck converter", International Journal of Power Electronics and Drive System (IJPEDS), vol. 10, no. 1, 2019.

[9] G. A. O.A. Hassan, C. Klumpner, "Design consideration for core material selection and operating modes for a high frequency transformer used in an isolated DC/DC converter," in European Conf. on Power Electronics and Application, 2016.

[10] M. Leibl, G. Ortiz, and J. W. Kolar, "Design and experimental analysis of a medium-frequency transformer for solid-state transformer applications," IEEE J. Emerg. Sel. Top. Power Electron, vol. 5, no. 1, pp. 110-123, 2017.

[11] H. Iman-Eini, S. Farhangi, J. L. Schanen, and M. Khakbazan-Fard, "A modular power electronic transformer based on a cascaded H-bridge multilevel converter," Electr. Power Syst. Res., vol. 79, no. 12, pp. 1625-1637, 2009.

[12] B. Rao et al., "Reduction of leakage inductance and AC resistance of planar transformers by optimising the current distribution," IET Power Electronics, Institution of Engineering and Technology, vol. 11, no. 3, pp. 501-506, 2018.

[13] A. Atalla et al., "Advancements in high power high frequency transformer design for resonant converter circuits," ECCE 2016 - IEEE Energy Convers. Congr. Expo. Proc., 2017.

[14] H. J. Choi and J. H. Jung, "Practical design of dual active bridge converter as isolated bi-directional power interface for solid state transformer applications," J. Electr. Eng. Technol., vol. 11, no. 5, 2016.

[15] M. C., B. H., W. C., and G. S, "Operation, design and control of dual H-Bridge-based isolation bidirectional DCDC converter," IET, vol. 1, pp. 507-517, 2008.

[16] K. George, "Solid-state transformers for interfacing solar panels to the power grid: an optimum design methodology of a high frequency transformer for dc-dc converter applications," vol. 20, 2016.

[17] P. S. Kumar, "Design of high frequency power transformer for switched mode power supplies," vol. 2, 2016.

[18] A. J. Hanson, J. A. Belk, S. Lim, C. R. Sullivan, and D. J. Perreault, "Measurements and performance factor comparisons of magnetic materials at high frequency," IEEE Trans. Power Electron., vol. 31, no. 11, pp. 7909-7924, 2016.

[19] R. Garcia, A. Escobar-Mejía, K. George, and J. C. Balda, "Loss comparison of selected core magnetic materials operating at medium and high frequencies and different excitation voltages," 2014 IEEE 5th Int. Symp. Power Electron. Distrib. Gener. Syst. PEDG 2014, 2014. 
[20] T. V. Nguyen, T. V. Vo, P. Petit, M. Aillerie, and N. T. Pham, "Optimized pulse transformer for step-up DC-DC converter," in Energy Procedia, vol. 119, pp. 930-937, 2017.

[21] Y. Xie, J. Sun, and J. S. Freudenberg, "Power flow characterization of a bidirectional galvanically isolated highpower DC/DC converter over a wide operating range," IEEE Trans. Power Electron., vol. 25, no. 1), pp. 54-66, 2010.

[22] J. Zhang, J. Liu, J. Yang, N. Zhao, Y. Wang, and T. Q. Zheng, "A modified DC power electronic transformer based on series connection of full-bridge converters," IEEE Transactions on Power Electronics, 2018.

[23] B. Zhao, Q. Song, W. Liu, and Y. Zhao, "Transient DC bias and current impact effects of high-frequency-isolated bidirectional DC-DC converter in practice," IEEE Trans. Power Electron., vol. 31, no. 4, pp. 3203-3216, 2016.

[24] A. Kadavelugu et al., "High-frequency design considerations of dual active bridge $1200 \mathrm{~V}$ SiC MOSFET DC-DC converter," Conf. Proc. - IEEE Appl. Power Electron. Conf. Expo. - APEC, pp. 314-320, 2011.

[25] K. D. Hoang and J. Wang, "Design optimization of high frequency transformer for dual active bridge DC-DC converter," in Electrical Machines (ICEM), 2012 XXth International Conference, pp. 2311-2317, 2012.

[26] T. Lambda, "PF500A-360 power supply module specification," 2012. [Online]. Available: https://uk.tdklambda.com/. [Accessed: Dec-2018].

[27] TDK-Lambda, "PF-A series application notes," 2012. [Online]. Available: https://product.tdk.com/info/en/catalog/datasheets/pf-a_e.pdf. [Accessed: Jan-2019].

[28] J.-K. Kim et al., "Start-up inrush current reduction technique of asymmetrical half-bridge DC/DC converter for PC power supply," in 2007 7th Internatonal Conference on Power Electronics, pp. 243-245, 2007.

[29] M. Wani, K. Kurundkar, and M. P. Bhawalkar, "Use of power electronic converters to suppress transformer inrush current," in 2012 IEEE International Conference on Power Electronics, Drives and Energy Systems (PEDES), pp. 1-5, 2012.

[30] H. Hoshi, T. Tanaka, M. Noritake, T. Ushirokawa, K. Hirose, and M. Mino, "Consideration of inrush current on DC distribution system," in Intelec 2012, pp. 1-4, 2012.

[31] P. Prasad and V. P. Dhote, "A method for reducing inrush current and transient overvoltage in three phase capacitor bank," in 2016 IEEE 1st International Conference on Power Electronics, Intelligent Control and Energy Systems (ICPEICES), pp. 1-6, 2016.

\section{BIOGRAPHIES OF AUTHORS}

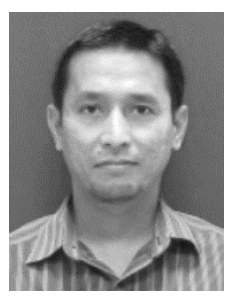

Omar Abu Hassanis a lecturer at the Department of Electrical Engineering, and is lecturer of the Faculty of Engineering Technology, Universiti Tun Hussein Onn Malaysia (UTHM). He received the B.Eng degree in Electrical Engineering from Universiti Teknologi Malaysia, Johor, Malaysia in 2005, Then, he received his Master degree in Renewable Energy System from the University of Nottingham, UK in 2008. He has been working toward the Ph.D degree on the construction and optimization of magnetic material for power electronic converter in Universiti Tun Hussein Onn Malaysia, Johor, Malaysia. His research interest are in DC/DC power converter for renewable-grid integration and smartgrid and IoT implementation for smart housing monitoring system.

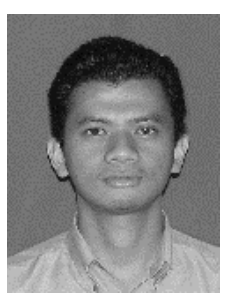

Shamsul Aizam Zulkifli is an Associate Professor and Head of Department at the Department of Electrical Power Engineering, Faculty of Electrical and Electronic Engineering, Universiti Tun Hussein Onn Malaysia (UTHM). He received the B.Eng degree in Electrical \& Electronic Engineering from Universiti Putra Malaysia (UPM), Selangor, Malaysia in 2003. Then he received his Master degree in Electrical Power Engineering from UPM in 2006. In 2012, he received Ph.D in Electrical Engineering from Loughborough University, UK. His research interest are in Power converter control applications, smart grid power control and advance control in power converters.

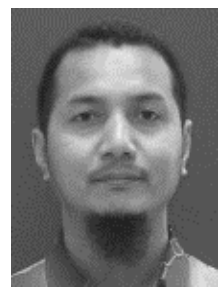

Mohd Shamian Zainal is a Senior lecturer at the Department of Electrical Engineering, and is lecturer of the Faculty of Engineering Technology, Universiti Tun Hussein Onn Malaysia (UTHM). He received the B.Eng degree in Electrical Engineering from Universiti Teknologi Malaysia, Johor, Malaysia in 2001. Then he received his MSc degree in Electrical Engineering from UTHM in 2003. In 2010, he received Ph.D in Computer Engineering from Hokkaido University Japan. His research interest are in FPGA implementation and Optimization monitoring system 

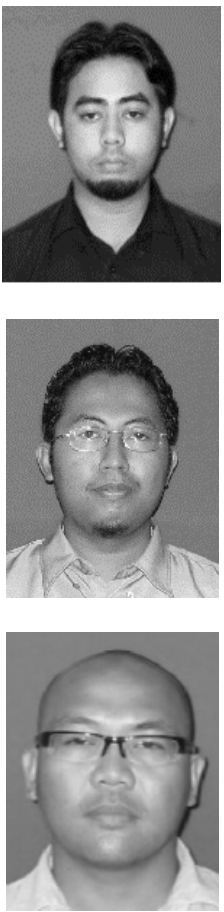

Ahmad Alabqari Ma' Radzi was born in Kuala Lumpur, Malaysia on August 4th 1980. He received the B.Eng degree in microelectronic engineering from Universiti Kebangsaan Malaysia in 2002. Then he joined UTHM and further his MSc degree in micro and nanoelectronic engineering from Universiti Kebangsaan Malaysia in 2007. His research interest are in sensors, power electronics and IoT implementation for smart housing monitoring system

Muhammad Shukri Ahmad is a Senior Lecturer in Centre for Diploma Studies, Universiti Tun Hussein Onn Malaysia, and also the head of the Development of Educational STEM kit (DESK). Previously he served in Faculty of Electrical and Electronics Enginnering, Universiti Tun Hussein Onn Malaysia. His research interest is currently in developing STEM module and kits for schools, IoT and 3d design and printing

Tengku Nadzlin Tengku Ibrahim was born in Pahang, Malaysia on October 15th 1980. He received the B.Eng degree in electrical, electronic and information engineering from Nagaoka University of Technology, Japan in 2004. Then he joined UTHM and further his M.Eng degree in electrical, electronic and information engineering also from Nagaoka University of Technology, Japan (2008) where he works on fabrication of organic thin films and its electrical and optical properties. His research interest are in fabrication of thin films and IoT implementation for smart housing monitoring system 